\title{
Integrated Reporting: Perspectives of Corporate Report Preparers and Other Stakeholders
}

\author{
D. Adhariani \\ Universitas Indonesia, Depok, Indonesia) \\ Charl de Villiers \\ The University of Auckland, and University of Pretoria)
}

\section{Please cite as:}

Adhariani, D. \& De Villiers, C. 2018. Integrated Reporting: Perspectives of Corporate Report Preparers and Other Stakeholders, Sustainability Accounting, Management and Policy Journal, forthcoming.

\begin{abstract}
Purpose: To explore the perspectives of corporate report preparers and other stakeholders on integrated reporting (IR) in a major Southeast Asian economy.

Design/methodology/approach: A survey is used to explore perspectives on IR.

Findings: There is a limited level of knowledge regarding integrated reporting, but a high level of interest. Corporate report preparers paradoxically state that they can see the benefits of integrated reporting, yet they are reluctant to implement it.

Practical implications: Changes to university curricula, training sessions, seminars, and conferences may be needed to disseminate information regarding integrated reporting.

Social implications: Integrated reporting implementation may be stymied by the low levels of knowledge in Southeast Asia and hence lack of demand from stakeholders. High-quality reporting generally supports capital flows into a region and thus influences economic and social well-being. The integrated financial and non-financial information needs of stakeholders thus have an indirect impact on society.
\end{abstract}

Originality/value: Southeast Asia is an economic powerhouse and home to hundreds of millions of people. It is important to understand the potential for integrated reporting in this region. This is one of the first survey of its kind to explore these matters.

Keywords: integrated reporting, report preparers, stakeholders 


\section{Introduction}

Global competition, technological advancements, and increased regulations have significantly changed the business landscape. In addition, the global financial crisis highlighted the shortcomings of traditional financial reporting, including the lack of future orientated information and the failure to fully account for intangibles. Furthermore, companies increasingly publish stand-alone social and environmental reports and provide such information in separate sections in their annual reports (Cho et al., 2009), resulting in social and environmental disclosures being disconnected from financial disclosures, making it difficult to assess their impact (de Villiers and Hsiao, 2018). Integrated reporting (IR) is potentially able to address these challenges (de Villiers et al., 2014). Introduced in practice in the early 2000s, IR has since been promoted by the International Integrated Reporting Council (IIRC), which was established in 2010, in response to growing stakeholder demands for a broader range of decision-useful information, compared to conventional corporate financial reports (de Villiers et al., 2017a). Research indicates that IR could assist in formulating strategy (Adams, 2015), assessing organisational value (de Villiers et al., 2017b), facilitating capital growth from new foreign investors (Macias and Farfan-Lievano, 2017), evaluating organisations' impact on human rights and other global issues (Abeysekera, 2013), benefit the public sector (Guthrie et al., 2017), improve stewardship and accountability (IIRC, 2013), and explain why market values of companies exceed book values (Serafeim, 2015). Information reported in such an integrated fashion allows an organisation to present specific strategies and long-term prospects to its investors, stakeholders and other decision makers (e.g., potential customers and prospective employees) (Ighian, 2015; Eccles and Armbrester, 2011).

Despite the enthusiasm in countries such as South Africa, IR has not been widely adopted in Asia (Dumay et al., 2017). For instance, a survey conducted by the Malaysian Institute of Accountants (MIA) and the Association of Chartered Certified Accountants (ACCA) in 2016 found that the uptake of IR in Malaysia is in its infancy and that knowledge of IR among corporate report preparers and the users of these reports, is still relatively low (MIA-ACCA, 2016). Just over half of the respondents were found to have little or no knowledge of IR, whereas only $13 \%$ claimed to have good or in-depth knowledge (MIA-ACCA, 2016). Similar conditions were found in other Southeast Asian countries such as Singapore and Indonesia (ISCA-NUS, 2014).

Since IR is often viewed as the next step in social and environmental disclosures (de Villiers et al., 2014), understanding the level of uptake of such disclosures may provide an early indication of the readiness of countries in the ASEAN (Association of South East Asia Nations) region to move towards IR. A report released by the Centre for Governance, Institutions, and Organisations in 2016 found that the overall level of sustainability reporting among the top 100 companies in four ASEAN countries (Indonesia, Malaysia, Singapore, and Thailand) was adequate. The report 
also found that only a small proportion of ASEAN companies disclosed information on materiality. The IR framework suggests the need for a stakeholder-driven materiality assessment exercise to determine the contents and focus of an integrated report (Lai et al., 2017). Given the importance of stakeholders in IR, the present study examines the perspectives of corporate report preparers and other stakeholders (i.e., users, auditors, investors, and academics) in order to determine if Indonesia is ready to move towards IR. This is especially important, given the IIRC's belief that IR will become the norm in Asia over the next decade (Colvert, 2016).

The present study starts with the survey used by the MIA-ACCA, but includes three additional questions, derived from theory, related to the motivation to move towards IR, the level of knowledge regarding sustainability reporting and IR, and the perceptions regarding the role of leadership in IR implementation. The study aims to explore the level of IR knowledge in Indonesia, as well as how IR is perceived by Indonesian stakeholders. The main research questions are: "What is the current level of IR knowledge in Indonesia?", "What are the perceived challenges and benefits for report preparers and stakeholders?", and "If IR is to be adopted in Indonesia, what form should adoption take and what is needed to support widespread adoption?" To answer these research questions, we survey corporate report preparers and other stakeholders (investors, analyst, auditor, academics and others).

Although similar research has been conducted in Malaysia, the research results cannot be expected to be automatically extended to Indonesia due to significant contextual differences in terms of corporate reporting and use of corporate information. According to Mahzan (2017), the Malaysian Institute of Accountants (MIA) is the primary advocate for integrated reporting in the Malaysian capital market since IR was identified as the way forward for effective disclosure of non-financial information in the Corporate Governance Blueprint 2011. IR was also proposed as one of the exemplary practices in the Public Consultation Paper of the Malaysian Code on Corporate Governance 2016 (MCCG) and was subsequently incorporated in the MCCG. In Indonesia, the Indonesian Institute of Accountants (IAI) and the National Center for Sustainability Reporting promote IR, but unlike Malaysia, these initiatives are without official backing. IR implementation is low in Indonesia, even compared to Malaysia. One of our IAI respondents argued that the slow adoption in Indonesia might be because companies have not taken ownership of financial reporting (relying on their auditors), and that IR will demand more input from companies.

This study can potentially inform Indonesian regulators tasked with the development of a reporting framework to support the provision of useful information to a broad spectrum of stakeholders, including the providers of capital. For example, a respondent from the Indonesian Authority of Financial Services stated that, although IR has not been mandated, the formats and contents of Indonesian annual reports are starting to informally follow the IR framework. This trend is driven by regulation, i.e., Regulation No. 51/POJK.03/2017 on the implementation of 
sustainable finance for financial services institutions and public companies, which prescribes the disclosure of sustainability information, either in a stand-alone report or integrated into an annual report.

Indonesia is a newly industrialised country in Southeast Asia, along with Malaysia, Thailand and the Philippines. Indonesia is the largest Southeast Asian country in terms of population (261 million), is the only member of the G-20 in the region, and has the largest economy, with a GDP of US\$3.243 trillion (CIA, 2017). The ASEAN Economic Community, which formed in December 2015, is expected to increase capital flows from abroad to the region, but this requires companies to provide information that is useful to international capital providers and potential investors. According to Soyka (2013), IR may be more appropriate for this purpose than traditional annual and sustainability reports.

Overall, this study contributes to the literature in several ways. First, it explores the opinions of various stakeholders regarding IR, which has not been undertaken in Indonesia. Second, given the motivation of local investors to play a larger role in the Indonesian capital market (Dvořák, 2005; Kartini, 2017), it is timely to obtain a better understanding of their views regarding IR. Third, it is also important to consider the perspectives of academics, since the accounting curriculum may have to respond to a move towards IR (Owen, 2013). The accounting curriculum has already included IR in the ACCA and CIMA curriculum since 2014; however, the higher education accounting curriculum in Indonesia does not yet mention IR. Finally, since previous studies on IR generally focused on developed countries and South Africa (Rensburg and Botha, 2014; Atkins and Maroun, 2015), the findings of the present study will be useful to companies, policymakers and researchers, as it gives an indication of the level of IR knowledge and the perceptions around IR. As such these findings may be useful to better understand the likely development of IR in ASEAN emerging markets, such as Indonesia.

The remainder of this paper is organised as follows. Section 2 provides the theoretical background and reporting framework in Indonesia, while Section 3 describes the methodology used in this study. Section 4 discusses the findings before Section 5 presents the conclusion as well as recommendations for policymakers and future research.

\section{Background and Literature Review}

\subsection{The Indonesian Context}

The name 'Indonesia' is derived from the Greek name 'indos nesos,' meaning 'islands near India.' Consisting of five main islands (Sumatra, Kalimantan, Sulawesi, Java and Papua) and 14,572 smaller islands, Indonesia is the largest archipelagic country in the world. Although Java is the smallest of the main islands, with only $6.9 \%$ of the country's landmass, more than $70 \%$ of Indonesia's total population, or approximately 180 million people, reside on the island (CIA, 2017; Tsamenyi et al., 2008). According to the United Nations Development Program, 
Indonesia's Human Development Index value in 2015 was 0.689 , placing it at 113 out of 188 countries/territories or the 'medium human development' category. This indicates that the country has low-income levels, low levels of education and poor health. As the fourth most populous country in the world, with more than 260 million people (as of December 2017), it has been extremely vulnerable to social and environmental problems, including illegal logging, deforestation and related wildfires (producing heavy smog over parts of Indonesia, Malaysia and Singapore), over-exploitation of marine resources and environmental problems associated with rapid urbanisation and economic development (e.g. air pollution, traffic congestion, poor garbage management and unreliable water/wastewater services).

Dealing with social and environmental problems requires the involvement of various parties, including the companies that contribute to such problems through their business and operational activities. In this regard, the Indonesian government has enforced companies to carry out social and environmental responsibility activities. In addition, it has stipulated that companies listed on the Indonesian Stock Exchange must disclose their social and environmental responsibilities in their annual reports. This requirement is stated in the Indonesian Government's Regulation No. 40/2007 concerning limited liability companies and Regulation No. 47/2012 regarding companies' social and environmental responsibilities, as well as in the Financial Service Authority's Regulation No. 29/POJK.04/2016 on public firms' annual reports. However, since there are no standards specifying this disclosure, the level and quality of social and environmental disclosures vary.

The latest regulation is the Financial Services Authority's Regulation No. 51/POJK.03/2017 on the implementation of sustainable finance for financial services institutions, issuers and public companies. Although one respondent in this study (who works for the Indonesian Authority of Financial Services) stated that the regulatory body had made an effort to encourage companies to produce annual reports in an integrated manner, it does not specifically refer to IR.

\subsection{Research on Motivations for Reporting Choices}

Information asymmetries and agency problems are key drivers of disclosure decisions (de Villiers, 1999). This is especially relevant for shareholders, who know less about their investments than the managers (or agents) of the companies (de Villiers and van Staden, 2012). In Indonesia, where more than two-thirds of firms are controlled by family-related shareholders, the agency problem is acute and specific to minority shareholder rights (Claessens et al., 1999; Claessens et al., 2000), as well as other stakeholders. Therefore, apart from the shareholders, the present study also examines the perspectives of other stakeholders, including academics and the government, for whom general accountability is important. 
Apart from agency theory, the motivation for providing disclosures can be explained by legitimacy theory, stakeholder theory, and institutional theory. According to legitimacy theory, organisations provide corporate reports in order to create the image of being legitimate businesses with legitimate activities for their stakeholders (Ahmed Haji and Anifowose, 2016; de Villiers and van Staden, 2006; Deegan, 2002). Based on stakeholder theory, disclosures are provided to satisfy the needs of stakeholders, which include equity investors, employees, analysts, advisers, business contact groups, government, taxpayers, ratepayers, consumers, lenders, creditors, suppliers, labour unions, the media, political parties, consumer/environmental protection societies and regional pressure groups (Deegan and Rankin, 1997). This means that the number of potential users of integrated reports is significant, aside from shareholders and creditors (Esterhuyse and Wingard, 2016). As for institutional theory, corporate reports respond to institutional pressures (Raaijmakers et al., 2015), and these pressures come from regulatory bodies (e.g., the government and/or professional bodies), societal expectations, and prominent organisations.

Disclosures in Indonesia have also been found to be motivated by the reasons posited by these theoretical perspectives. Basalamah and Jermias (2005) found that Indonesian companies reported and audited social and environmental matters, following "threats to the company's legitimacy and ongoing survival" (pp. 109). Gunawan (2007; 2015) report survey evidence that legitimation and stakeholders demands drive CSR disclosures in Indonesia. Joseph et al. (2016) use an institutional theory perspective to portray the anti-corruption practice disclosure among Malaysian and Indonesian CSR best practice companies and found higher disclosures in Indonesia, due to more coercive pressure to do so. Other research use agency theory to examine the potential of corporate governance mechanisms in Indonesian companies to reduce information asymmetry through disclosure, see Utama (2012) and Utama and Utama (2014) regarding the disclosure level of related party transactions; and Siregar and Bachtiar (2010) regarding corporate social reporting.

Finally, according to Eccles and Armbrester (2011), there are three reasons why companies provide disclosures in their corporate reports: internal benefits, external market benefits and the management of regulatory risks. While the theories above focus more on external factors (including the market and regulations), the "internal benefits" reason is an internal factor. Of course, these benefits need to outweigh the costs involved. Therefore, our survey also explores this issue by asking participants about their perceptions regarding the benefits and costs of providing IR disclosures.

\subsection{Research on user's perceptions of integrated reporting}

Apart from exploring corporate report preparers' perspectives, we also explore users' perceptions. The main focus is on shareholders' and potential investors' information needs. We 
explain the information needs of this group from an agency theory perspective, with the notions of decision usefulness, accountability and information asymmetry (de Villiers and van Staden, 2012). From this perspective, management knows more than shareholders and is likely to reveal only information favourable to themselves. Therefore, shareholders are expected to demand more manager accountability through additional disclosures (de Villiers and van Staden, 2010).

As we also explore other stakeholders' perspectives, the forms of accountability are different for different stakeholder groups. Hence the demand for corporate information can also be viewed from the perspectives of legitimacy, stakeholder, and accountability theory. Different stakeholder groups typically have different objectives in seeking corporate information. For example, shareholders require value-relevant information, whereas other stakeholder groups may be more interested in the natural environment, or in social objectives.

Several previous studies explore perceptions on IR in different countries from the perspective of different stakeholders. First, corporate report preparers' perspectives are investigated by Perego et al. (2016) using a sense-making perspective, suggesting that IR is perceived as a diverse and incoherent field, where progress is being made despite challenges. Chaidali and Jones (2017) found that trust towards IIRC -- the motives of the IIRC professionals and the credibility of the composition of the IIRC Board -- and concerns about the format of IR are important factors for corporate report preparers when considering IR implementation. Preparers also express concern regarding the uncertainty of any benefits of IR and the "lack of adequate and clear guidance, high preparation costs, the format, and the length of the report" (pp. 1).

Higgins et al. (2014) examined the institutionalisation process of IR adoption by undertaking semi-structured interviews with 23 Australian managers of early IR adopters. Higgins et al. (2014) found that IR implementation can, among other reasons, also be motivated by strategic imperatives. The challenges experienced by the early adopting managers include having to change corporate strategy, operating philosophy and reporting practices. Beck et al. (2017) use the legitimacy lens to explore an organisation's journey into non-financial reporting, which was initially motivated by a legitimacy crisis in public confidence to the present situation with the organisation embracing IR. Lodhia (2015) uses the theory of practice to explore IR implementation in an Australian customer owned bank, suggesting organisations need a good understanding of IR, and clear rules and guidelines, to be supported by ethical values, principles and associated structures and processes to ensure effective IR adoption.

Second, perceptions from shareholders and potential investors have also been investigated in previous research. Atkins and Maroun (2015) explore the initial reactions of South African institutional investors to the early integrated reports prepared by companies listed on the Johannesburg Securities Exchange, based on interviews with 20 experts from the South African investment community. IR is viewed positively, as it is seen as an improvement 
on the traditional annual report. Several flaws, including excessive length, repetition, and difficult-to-follow structures, still need to be improved in the future, as they can "detract from the usefulness of the reports and undermine the development of an integrated thinking ethos" (pp. 215). In contrast, Hsiao and Kelly (2017), using semi-structured interviews with 16 investment analysts in Taiwan, found that investors rely more on private information sources and quantitative data; while voluntary sustainability disclosures and sustainability performance are often not considered. In addition, Taiwanese investors are pessimistic about IR's potential to provide information for investment decision making, and they are not particularly familiar with the IIRC Framework. Slack and Tsalavoutas (2018) similarly report the low usefulness of IR to fund managers and equity analysts employed by global investment houses. Abhayawansa et al. (2018) also found that IR has little usefulness and hence is not relevant to sell-side analysts as the information contained in integrated reports is not sufficient and not in analysts' preferred format.

Perceptions of other stakeholders were explored in Stubbs and Higgins (2018), which investigated the preferences of nonfinancial information users in Australia for regulatory or voluntary approaches to IR. The study found more support for voluntary approaches and believed that market forces would ensure that IR becomes the reporting norm over time. Although the majority of participants thought that it was too early for regulatory reform, half of the investors support mandatory IR in order to encourage more substantive disclosures and enhance disclosure quality.

In the accounting education field, James (2015) investigated US accounting major students' perceptions regarding sustainability and integrated reporting. The study finds that accounting majors tend to support sustainability reporting of multiple performance indicators and perceive that sustainability reporting is more beneficial to large than to small and midsize companies. Students also opine that high-quality sustainability reporting standards, mandatory reporting, and the adoption of an integrated reporting format will enhance the quality of reporting.

Still, from a contemporary academic perspective, Dumay et al. (2017) identified the enablers, incentives, and barriers to IR and the IIRC Framework. Confusion about IR and the Framework, vague definitions of integrated thinking and value creation concepts, questionable usefulness for the value relevance and lack of regulation, as well as inadequate internal processes are identified as barriers and challenges to IR implementation.

Unlike most of these prior studies, our research focuses on an emerging market, namely Indonesia, where IR has not been widely adopted. Our study contributes to our understanding regarding the feasibility of IR adoption in emerging markets and potentially informs regulators and the IIRC. 
Table 1. Conceptual Framework

\section{Theoretical perspectives}

Preparers' perceptions:
Motivations for reporting
-agency theory (managers' motivations)
-legitimacy theory (societal norms)
-stakeholder theory (specific groups' needs)
-institutional theory (towards standardisation)

\section{Users' perceptions:}

Demand for corporate information

-agency theory notions of:

-decision usefulness

-accountability

-information asymmetry

-stakeholder theory (stakeholders' demand and

pressures for corporate information)

\section{Research Questions}

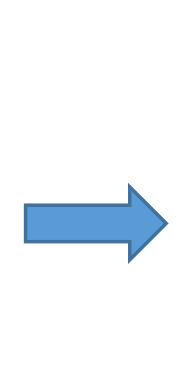
challenges and benefits of IR

from report preparers' and

stakeholders' perspective?

If IR is to be adopted in

Indonesia, what form should adoption take and what is

needed to support widespread

adoption?

\section{Survey Questions}

. Level of knowledge of IR

2. Eagerness to learn more about IR

3. Perceptions of the recipients and

preparers of IR

4. The role of leadership

5. The need for IR assurance

. Reasons for adopting IR

2. Perceived benefits of IR

3. Consideration of the costs and

benefits

4. Perceived challenges

1. Implementation and impact

2. Support, promotion, and

training 


\subsection{Conceptual framework}

Based on the theoretical perspectives and previous research, the conceptual framework employed in this study is presented in Table 1 to show the conceptual underpinning of the survey design to answer the research questions.

\section{Research Method}

The questionnaire in this study was adapted from the Malaysian MIA-ACCA (2016) survey. Given the low level of IR adoption in Malaysia and Indonesia, this approach is appropriate and allows for comparisons between the two countries. In addition, similar research questions are appropriate in the two countries at this early stage of IR development, i.e., regarding the level of knowledge, perceptions on the costs and benefits of IR and the feasible of IR implementation.

The questionnaire was distributed from July to November 2017. It was pilot tested on 20 accounting students who studied sustainability accounting and reporting at the Universitas Indonesia. The pre-survey responses were not included in the results reported in this paper. To enable a comparison with other Southeast Asian countries and enhance the participants' responses, the MIA-ACCA (2016) survey was translated from English into Indonesian and was modified by including three additional questions (Table 2).

Table 2. Additional Questions

\begin{tabular}{|c|c|}
\hline Questions & $\begin{array}{c}\text { The motivations for including the } \\
\text { questions }\end{array}$ \\
\hline $\begin{array}{l}\text { What do you believe would provide the } \\
\text { greatest motivation for your company to } \\
\text { prepare integrated reports? (You can choose } \\
\text { more than one answer): } \\
\text { a. The knowledge that your competitors/peers } \\
\text { are preparing integrated reports. } \\
\text { b. It is mandated by the accounting profession. } \\
\text { c. It is mandated by corporate regulations. } \\
\text { d. To satisfy shareholders and other } \\
\text { stakeholders. } \\
\text { e. Other. }\end{array}$ & $\begin{array}{l}\text { To determine the consistency with the } \\
\text { theories discussed in this study (i.e., } \\
\text { stakeholder theory, legitimacy theory and } \\
\text { institutional theory). }\end{array}$ \\
\hline $\begin{array}{l}\text { If your company prepares separate } \\
\text { sustainability reports, will they be in addition to } \\
\text { the integrated reports? Why or why not? }\end{array}$ & $\begin{array}{l}\text { To determine whether the participants } \\
\text { understand the difference between } \\
\text { sustainability reports and integrated reports. } \\
\text { Since the question requires participants to } \\
\text { have some knowledge of IR, we only } \\
\text { analysed responses provided by participants } \\
\text { ranking themselves at levels three to five. }\end{array}$ \\
\hline $\begin{array}{l}\text { How important is the role of leadership in } \\
\text { determining the introduction of IR? }\end{array}$ & $\begin{array}{l}\text { To gain an understanding of the participants' } \\
\text { views on the role of leadership so that } \\
\text { implications for top management can be } \\
\text { drawn. }\end{array}$ \\
\hline
\end{tabular}


Regarding the distribution of the questionnaires, the authors contacted the Indonesian Institute of Accountants (IAI), the participants in the general and executive training sessions held by CIMA-Indonesia and the Centre of Accounting Development (Pusat Pengembangan Akuntansi), the Universitas Indonesia and academics from various universities. Since this study used online questionnaires as a method of non-probability sampling, the actual response rate cannot be determined. In order to minimise non-response bias, the following four steps were taken: (1) A request to complete the questionnaire was made to individual members of the IAI (by one of its directors) and individual members in the training sessions held by The Centre of Accounting Development (by one of its staff members); (2) The participants were asked to complete the questionnaire even if they had little or no interest in IR or if their companies did not implement IR; (3) Online questionnaires were used to improve the response rate; and (4) The anonymity of the survey data was ensured. It is important to note that the participants were offered the possibility of receiving the results of the survey (by providing their email address), which seemed to increase their interest in IR.

\section{Findings}

\subsection{Respondents}

A total of 220 responses were received, but only 182 were valid for further analysis, due to incomplete answers. Their profiles are presented in Table 3.

Table 3. Respondents' Profiles

\begin{tabular}{|c|c|}
\hline Characteristics & $\begin{array}{l}\text { Percentage of total } \\
\text { respondents (182) }\end{array}$ \\
\hline \multicolumn{2}{|l|}{ Profession } \\
\hline $\begin{array}{l}\text { Preparer: responsible for finance and accounting (CFO, financial } \\
\text { controller, accountant, sustainability practitioner) }\end{array}$ & $37 \%$ \\
\hline Academic & $22 \%$ \\
\hline Auditor & $20 \%$ \\
\hline Investor/Analyst & $7 \%$ \\
\hline Other: consultant, the staff of a regulatory body, civil servant & $14 \%$ \\
\hline \multicolumn{2}{|l|}{ Member of the following professional accounting bodies: } \\
\hline Indonesia Institute of Accountants (IAI-Ikatan Akuntan Indonesia) & $47 \%$ \\
\hline $\begin{array}{l}\text { Other: CIMA, Indonesia Lecturer Forum, Institute of Internal } \\
\text { Auditors (IIA) }\end{array}$ & $1 \%$ \\
\hline Not a member of any professional body & $52 \%$ \\
\hline \multicolumn{2}{|l|}{ Work experience: } \\
\hline Less than 10 years & $41 \%$ \\
\hline $10-20$ years & $28 \%$ \\
\hline More than 20 years & $31 \%$ \\
\hline
\end{tabular}

According to Table 3, the respondents primarily consisted of users, non-members of a professional body and individuals with less than 10 years of work experience. The corporate report preparers in this survey operated in many different sectors, particularly in the 
manufacturing (21\%), energy and natural resources (13\%) and financial services (44\%) sectors. 'Academics' were defined as full-time lecturers at universities, with no consulting work outside of their university role. In this study, $9 \%$ of the respondents were part-time academics, and therefore included in the appropriate categories indicative of their main role, i.e. auditors and consultants.

First, the participants were asked to rate their knowledge of IR on a scale of 1 to 5 , ranging from 'Little or no knowledge' to 'Good or in-depth knowledge.' Table 4 summarises the responses.

Table 4. Level of Knowledge

\begin{tabular}{l|r}
\hline Little or no knowledge (Score of 1-2) & $41 \%$ \\
\hline Average knowledge (Score of 3) & $40 \%$ \\
\hline Good or in-depth knowledge (Score of 4-5) & $19 \%$ \\
\hline
\end{tabular}

Compared to the MIA-ACCA (2016) survey in which $13 \%$ of the respondents in Malaysia had the good or in-depth knowledge, the situation in Indonesia was slightly better (19\%). According to Table 5, the investors/analysts group had the highest average score of 3.3. However, an ANOVA test (untabulated) shows that the average scores of the groups are not statistically significantly different, i.e. the groups in the study had a similar level of knowledge.

Table 5. Level of Knowledge

\begin{tabular}{|c|c|c|}
\hline Group & Average score & Variance \\
\hline Corporate Preparers & 2.438596 & 1.072055 \\
\hline Auditors & 2.925926 & 1.609687 \\
\hline Investors/Analysts & 3.333333 & 0.333333 \\
\hline Academics & 2.454545 & 1.005682 \\
\hline Other & 2.347826 & 1.418972 \\
\hline
\end{tabular}

We also perform independent samples t-tests for the level of knowledge between groups (shown in Table 6). There is only one moderately statistically significant difference in average scores between groups, namely at the $10 \%$ of significance between corporate report preparers and auditors, with auditors claiming to be more knowledgeable, which may be due to wider exposure on the latest corporate reporting updates.

Table 6. Independent Sample t-Test for the Level of Knowledge

\begin{tabular}{|c|c|c|c|c|}
\hline $\begin{array}{c}\text { Sig. (2 tailed) } \\
\text { Mean difference }\end{array}$ & Auditors & Investors/Analysts & Academics & Other \\
\hline Corporate & $0.065^{*}$ & 0.145 & 0.943 & 0.735 \\
Preparers & -0.487 & -0.895 & -0.016 & 0.091 \\
\hline Auditors & & 0.591 & 0.113 & 0.105 \\
& & -0.407 & 0.471 & 0.578 \\
\hline Investors/Analysts & & & 0.147 & 0.176 \\
& & & 0.879 & 0.986 \\
\hline Academics & & & & 0.718 \\
& & & & 0.107 \\
\hline
\end{tabular}

*significant at the $10 \%$ level. 
We also conducted a t-test between the investors/analysts group and the other groups combined, since the former had the highest score. Investors/analysts had a higher level of claimed knowledge compared to other groups as a whole at the $10 \%$ significance level, i.e., moderately significant.

Table 7. T-test of the Level of Knowledge

Two-sample T-test Assuming Unequal Variances

\begin{tabular}{lcc}
\hline & Investors/Analysts & $\begin{array}{c}\text { Other } \\
\text { groups }\end{array}$ \\
\hline Mean & 3.33 & 2.52 \\
Variance & 0.33 & 1.23 \\
df & 2 & \\
T-statistic & 2.34 & \\
P $(\mathrm{T}<=\mathrm{t})$ one-tail & $0.07^{*}$ & \\
T-critical value one-tail & 2.92 & \\
\hline
\end{tabular}

*significant at the $10 \%$ level.

Similar to the MIA-ACCA (2016) survey, the low level of knowledge in the Indonesian sample is understandable, given that IR is a new global initiative and the take-up by companies has been limited. In fact, as of December 2016, there were fewer than 10 Indonesian integrated reports publishing companies. Moreover, there were two misconceptions found in the responses. First, 34\% of the respondents believed that sustainability reporting is a subset of IR (34\%). Second, $7 \%$ of the respondents believed that sustainability reporting is a perfect substitute for IR. These two misconceptions demonstrate low levels of knowledge among many respondents who did not understand that IR and sustainability reporting overlap, but are not the same. Only $11.7 \%$ of the respondents correctly stated that the two approaches overlap, which is close to the finding in the Malaysian context (12.4\%).

We further explore in more depth the responses provided by participants with some knowledge of IR (giving themselves a score of 3-5) for the question of "If your company prepares separate sustainability reports, will they be in addition to the integrated reports? Why or why not?" Only $26 \%$ of respondents with a score of 3 and above answered that the information in sustainability reports could be developed further to prepare an integrated report. This finding emphasises the low level of IR knowledge mentioned previously.

The low level of knowledge and the misconceptions found among respondents implies there may be a need to provide IR training and to promote IR, should IR become the reporting norm. This is further discussed in the next sections on support, promotion, and training.

\subsection{Interest in Learning More about IR}

Despite the low level of knowledge found in this study, $95 \%$ of the corporate report preparers and $98 \%$ of the other stakeholders stated that they were eager to learn more about IR. 
Some of the participants also provided suggestions on the mediums that could be used to raise awareness of IR. For example, they called for academics to create teaching courses. Moreover, they suggested that the costs of training/seminars should be reduced in order to entice more participants to attend such events, which, in turn, could help raise awareness of IR.

Among corporate report preparers with some knowledge of IR (three or above on a five-point scale), $31 \%$ state that their company would consider implementing IR, while the majority (58\%) are unsure. Only $11 \%$ rule out the possibility of adopting IR. The "Unsure" and "No" responses may well be driven by respondents' limited IR knowledge and knowledge around IR implementation, such as expected costs/benefits, and implementation challenges. Furthermore, since IR adoption is voluntary, the decision to implement IR is influenced by the perceived benefits to the company and its shareholders.

\subsection{Reasons for Adopting IR}

Theoretically, the motivations for a company to adopt IR can be explained by agency theory, stakeholder theory, legitimacy theory and institutional theory. We explore the reasons respondents state have, or may, lead their organisations to adopt IR and also show the answers of respondents with some knowledge of IR (three or above on a five-point scale) separately see Table 8. Respondents were allowed to select more than one reason.

Table 8. Motivations for IR Adoption

\begin{tabular}{|l|c|c|}
\hline \multicolumn{1}{|c|}{ Motivation } & $\begin{array}{c}\text { Percentage of all } \\
\text { respondents }\end{array}$ & $\begin{array}{c}\text { Percentage of } \\
\text { knowledgeable } \\
\text { respondents }\end{array}$ \\
\hline To satisfy shareholders and other stakeholders & $63 \%$ & $66 \%$ \\
\hline It is mandated by corporate regulations & $33 \%$ & $41 \%$ \\
\hline $\begin{array}{l}\text { The knowledge that your competitors or similar } \\
\text { companies/organisations are preparing integrated } \\
\text { reports }\end{array}$ & $49 \%$ & $43 \%$ \\
\hline $\begin{array}{l}\text { It is mandated by the accounting profession } \\
\text { Other: }\end{array}$ & $33 \%$ & \\
\hline - To increase the accuracy of financial information \\
- To increase transparency \\
- To show the value of utilising various resources \\
- To publish reports more quickly \\
- To promote integrated thinking in management
\end{tabular}

The questions map to the different theories often used to explain the motivation to provide voluntary information. By far the most popular reason, stakeholder satisfaction, can be said to relate to stakeholder theory. The second most popular reason could be characterised as mimicking others (institutional theory), or perhaps as following similar 'societal' norms (legitimacy theory). The existence of information asymmetry as predicted by agency theory is reflected in the reason categorised as "Other"; that is, the motivations stem from the objectives to increase transparency and accuracy of financial information. These findings 
are consistent with previous studies (Roberts, 1992; de Villiers and Vorster, 1995; Deegan and Rankin, 1997; and García-Sánchez, Rodríguez-Ariza and Frías-Aceituno, 2013). However, as Gray et al., (1995, p. 47) suggested, the 'theory need not be competitor theories but may if analysed appropriately, be seen as alternative and mutually enriching theories from alternative levels of resolution.' Thus, the motivations for companies to adopt IR may be diverse. For instance, new regulations will have to be followed (coercive isomorphism), and widespread adoption may also lead to a desire to imitate other organisations (mimetic isomorphism) and eventually to view IR as 'the right thing to do' (normative isomorphism).

\subsection{Perceived Benefits of IR}

The motivations for adopting IR cannot be separated from the perceived weaknesses in the current reporting format. Among the corporate report preparers in this study, $28 \%$ were unsure whether the current corporate reporting framework allowed them to adequately communicate the value and value-creating potential of their company to investors and other stakeholders. However, $63 \%$ of respondents were sure that it did, perhaps representing resistance to change and a preference for the current reporting framework. The same resistance was also found among the users, with $65 \%$ of the respondents stating that they were still able to obtain sufficient information about the value and value-creating potential of the company through the current method of corporate reporting. However, both the corporate report preparers and the other stakeholders in this study believed that IR could improve the quality of reporting, as shown in Table 9. Again, we compare this result with the perceptions of knowledgeable respondents (three or above on a five-point scale) and found the similar results (78\% Yes, $20 \%$ Not sure, and $3 \%$ No).

Table 9. Perceived Benefits of IR in Increasing the Quality of Reporting

\begin{tabular}{|c|c|c|}
\hline $\begin{array}{c}\text { Will IR help improve the quality of } \\
\text { corporate reporting? }\end{array}$ & $\begin{array}{c}\text { Corporate report } \\
\text { preparers }\end{array}$ & $\begin{array}{c}\text { Other } \\
\text { Stakeholders }\end{array}$ \\
\hline Yes & $60 \%$ & $83 \%$ \\
\hline No & $3 \%$ & $1 \%$ \\
\hline Not sure & $37 \%$ & $16 \%$ \\
\hline
\end{tabular}

The findings are quite different from those in the Malaysian context. More specifically, the MIA-ACCA (2016) survey found that there were demands for clearer reporting of how companies create value and describe their value-creating potential. In this regard, the wider adoption of IR by companies could help meet investors' and users' information needs. In the Indonesian context, although the preparers and the users were generally satisfied with the current reporting framework, they believed that the adoption of IR could increase the quality of reporting. This finding implies that, unless regulations by the government or the accounting 
profession mandate that IR is adopted, the publication of integrated reports will remain a voluntary option. Moreover, the percentages of the respondents who were unsure of the potential impact of IR (37\% of the preparers and 16\% of the users) highlight the need for various education activities (e.g., training and the dissemination of research) in order to increase the understanding of IR among these groups.

Finally, the knowledgeable respondents were asked to select the perceived benefits of adopting IR from a list (Diagram 1). The top three benefits included promoting integrated thinking, improving communication with external stakeholders and improving transparency and governance, all of which were in line with the MIA-ACCA (2016) survey. Of lesser importance were the benefits related to the perceived appreciation from capital markets in terms of easier access to capital, increased share price and lower cost of capital. The findings suggest that the information provided in IR may be of little use for capital market participants, which is consistent with Rensburg and Botha's (2014) finding in South Africa, Slack and Tsalavoutas (2018) for global investors, Abhayawansa et al. (2018) for sell-side analysts, and Hsiao and Kelly (2017) in Taiwan. Moreover, this indicates that corporate reporting is not used as the main source of financial and investment information, either because such reports are still symbolic in nature or because the investors must rely on additional information. According to Michelon et al. (2015), symbolic reporting practices portray 'corporations as genuinely committed to CSR,' rather than 'a substantive approach to CSR undertaken to carry out duties of accountability to stakeholders, which was also found by Nasution and Adhariani (2016) for the Indonesian context.

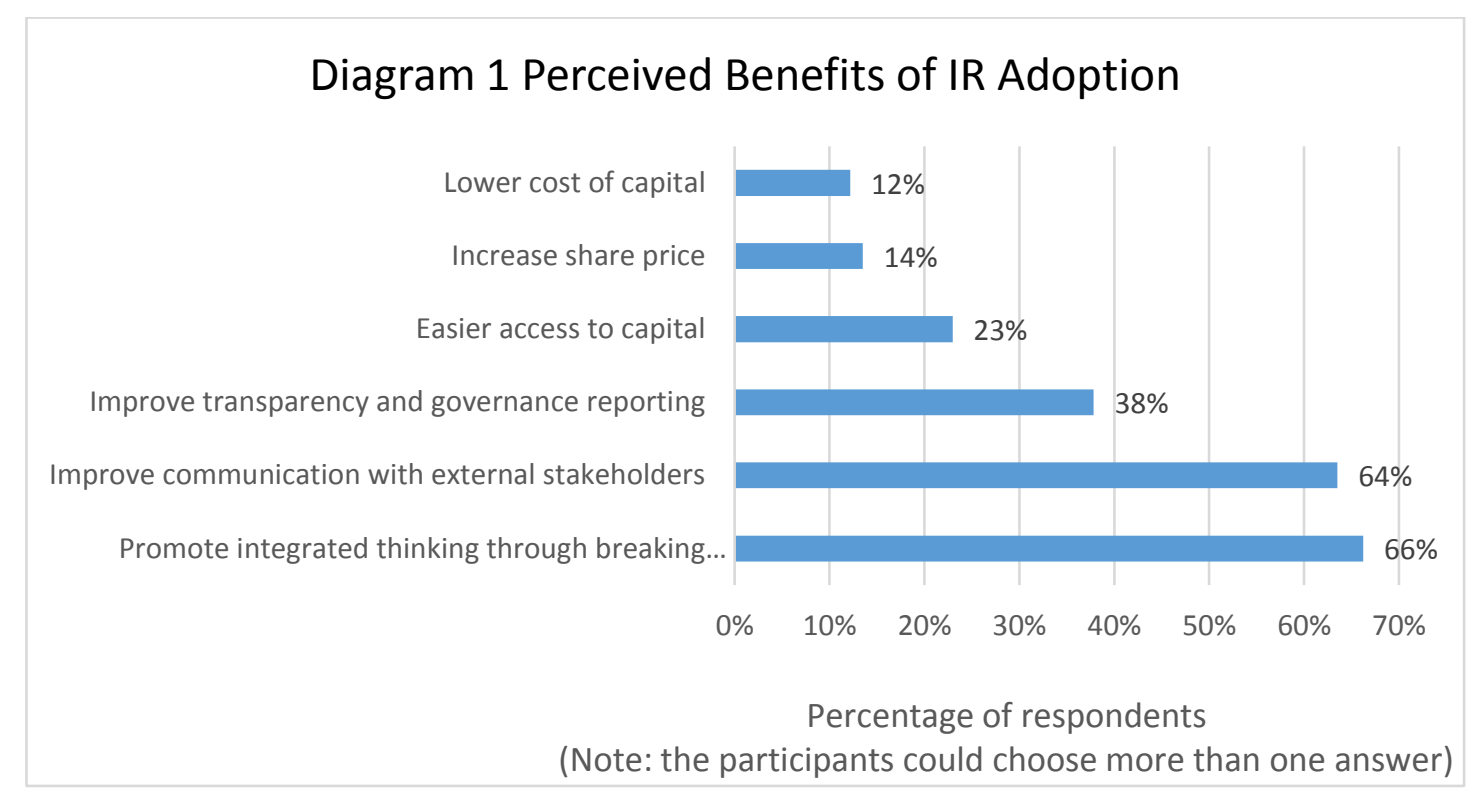

\subsection{Consideration of the Costs and Benefits}

Following the MIA-ACCA (2016) survey, the respondents were asked to score the costs and benefits of IR, with a baseline of 50 points for each aspect (Table 10). For example, if they 
believed that the benefits of reporting would increase by $10 \%$ under IR, then they would provide a benefit score of 55. Please refer to the Appendix for the wording of the question.

Table 10. Perceived Costs and Benefits Scores

\begin{tabular}{|l|c|c|c|}
\hline Group & $\begin{array}{c}\text { (Average) } \\
\text { Costs }\end{array}$ & $\begin{array}{c}\text { (Average) } \\
\text { Benefits }\end{array}$ & $\begin{array}{c}\text { T-test (p- } \\
\text { value) one- } \\
\text { tail }\end{array}$ \\
\hline Overall & 76.25 & 74.48 & 0.27 \\
\hline Preparers & 72.18 & 76.75 & $0.06^{*}$ \\
\hline $\begin{array}{l}\text { Non- } \\
\text { preparers }\end{array}$ & 80.09 & 73.34 & $0.09^{*}$ \\
\hline
\end{tabular}

*significant at the $10 \%$ level.

The overall scores provided by the respondents indicate that IR would bear considerable costs. For instance, the overall cost score was 76.25, which indicates that the costs will outweigh the benefits. We compare the perceived costs and benefits for knowledgeable respondents (three or higher on a five-point scale) and similarly find that the perceived costs (average of 78.89) outweigh the perceived benefits (average of 74.53). These findings were consistent with the views of the non-preparers in this study. Conversely, the preparers perceived that the benefits of IR would outweigh the costs, which differs from the Malaysian context. Hence, it is possible to conclude that, in the Indonesian context, the preparers believed that the costs are manageable.

In this regard, a one-tail t-test was conducted to further analyse the perceived differences between the preparers and the non-preparers in this study. Although the results indicated a moderate level of significance, the overall score was not statistically different. Thus, the two groups had different views on the costs and benefits of IR, but the preparers were more optimistic about this approach than their counterparts. There are two interpretations of this finding. First, as for the moderate significance of the higher level of knowledge possessed by the investors/analysts group, the optimistic score of the corporate preparers suggests that they have not realised the actual costs of implementing IR, even though the integration process was perceived as the greatest challenge (see Section 4.6). Second, the corporate preparers might have known about the costs of implementing IR, but given the advantages of IR, they perceived that the benefits would outweigh the costs. Regardless of the reason, future research should continue to examine the perceptions of corporate report preparers in regard to the costs and benefits of IR implementation.

\subsection{Perceived Challenges}

We asked knowledgeable respondents (three or above on a five-point scale) about the main challenges of adopting IR. As depicted in Diagram 2, the costs of preparation, lack of 
proper information systems, and fear of divulging market and/or price sensitive information are the top three challenges in IR implementation. This finding suggests that, even though the respondents thought that the benefits would outweigh the costs, there were still concerns about the cost of preparation. In addition, the lack of information system infrastructure to support IR is seen as an issue. Dumay et al. (2017) and Steyn (2014) similarly report inadequate information systems as a barrier to IR implementation. Other challenges from internal processes are lack of connectivity and integration processes, as well as a lack of support from top management and resistance from the ground level; which reflects the need for training and other educational activities for companies to prepare for IR adoption.

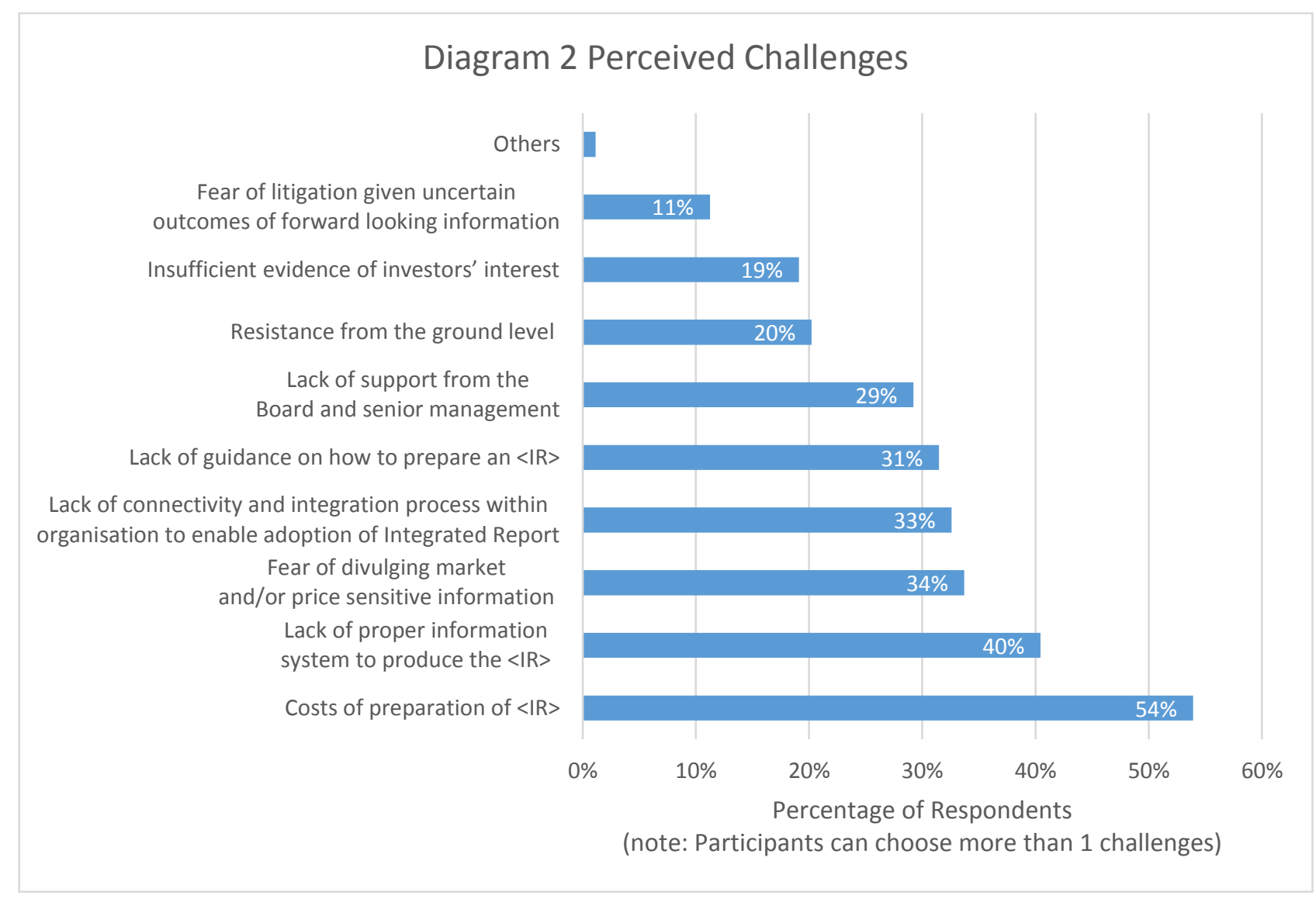

The lack of guidance on how to prepare an integrated report was also a key challenge (31\%). This finding indicates the need for technical advice and training. In addition, two of the respondents stressed the importance of regulations that can impose IR implementation. This echoed the other challenge of insufficient evidence of investors' interests (19\%), meaning that such implementation is more about conforming to the rules, than being market-driven. Similar challenges in terms of existing internal processes and unconvincing investors' interests are also found by McNally et al. (2017) even in the South Africa context which has been well known as a pioneer in the field of non-financial reporting.

Finally, a significant proportion (34\%) of the respondents were concerned about the fear of divulging market- and/or price-sensitive information. Similar to other reports, two of the 
respondents acknowledged that IR would be more subjective in nature; that is, a company will disclose beneficial information in order to reduce price sensitivity, which is in contrast to a company that only provides information to stakeholders other than shareholders, future investors, and creditors. As indicated by du Toit et al. (2017), significant uncertainty remains regarding the amount of disclosure required, even among South African companies.

\subsection{Perceptions on the Recipients and Preparers of IR}

Similar with the MIA-ACCA (2016) survey, the current and potential investors in the present study (identified by $84 \%$ and $66 \%$ of the respondents, respectively) were regarded as the primary recipients of integrated reports. Analysts (55\%) and regulators (53\%) were also considered as primary recipients by more than half of the corporate report preparers, as well as other stakeholders. In addition, wider audiences, such as the general public (36\%), customers (18\%) and suppliers (18\%), were identified. Several respondents also suggested other recipients, such as academics. Similar users were also mentioned by knowledgeable respondents, with slight differences in percentages (the top five were current investors (95\%), potential investor (66\%), regulators (60\%), analysts (59\%), and the general public (31\%)). This means that the respondents were able to identify the primary recipients of the integrated reports in the business and investment chain. This finding is consistent with the International IR Framework (IIRC, 2013, p. 4), which stated that the primary purpose of IR is to 'explain to providers of financial capital how an organisation creates value over time', with the goal of enabling 'a more efficient and productive allocation of capital'. Moreover, the choice of other recipients reflects the way that IR is expected to show stakeholders that the company is taking a holistic view of their interests by offering clean and concise reporting. Viewed from an agency theory perspective, this reflects the need for accounting information in terms of decision usefulness and information asymmetry (de Villiers and van Staden, 2012).

Respondents mostly expressed the view that top management was primarily responsible for preparing the integrated report, with $39 \%$ of respondents identifying the CEO, 30\% the Board of Directors, and $24 \%$ the CFO. Respondents also assigned primary responsibility to corporate communications/public relations (13\%), in-house sustainability practitioners (11\%), and surprisingly, auditors (9\%). The results, apart from the surprising 'auditor' responses, are similar to the responses of knowledgeable respondents, with 38\% identifying CEOs, $29 \%$ CFOs, 28\% Boards of Directors, and 28\% other preparers).

Approximately $84 \%$ of the respondents believed that those charged with governance over IR should be required to include a statement acknowledging their responsibility. This view was prevalent among the auditors (22\%), the users of financial statements (44\%) and the corporate report preparers $(58.6 \%)$. Several respondents commented that such a statement not only serves 
as a form of accountability for the IR process, but it increases the transparency and reliability of the integrated reports.

Finally, the respondents were asked to rate the importance of the role of leadership in IR implementation on a scale five-point scale, with one being 'Not important at all' to five being 'Very important.' Table 11 shows the means of their responses, indicating that leadership is seen as quite important.

Table 11. Perceptions of the Role of Leadership

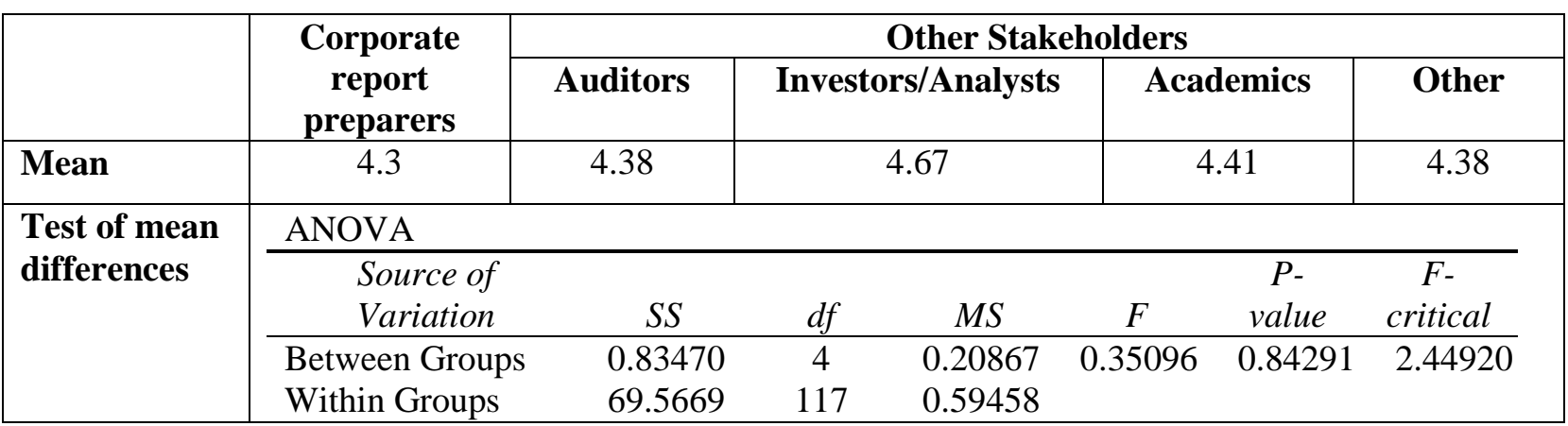

The findings of the ANOVA show that the corporate report preparers and the other stakeholders shared the same perceptions regarding the role of leadership in IR implementation. In addition, the corporate leaders were not only expected to be the drivers of IR implementation, but they were expected to ensure that all of the objectives are met.

\subsection{The Need for Assurance of IR}

Even though IR is relatively new in Indonesia, this study surveyed the need for assurance of IR. More than half of the respondents $(57 \%)$ believed that the stakeholders will require integrated reports to be audited in order to make them reliable, while $39 \%$ were unsure. Conversely, only $4 \%$ of the respondents did not expect the stakeholders to require such audits. Knowledgeable respondents share the same views (60\% Yes, 34\% Unsure, and 6\% No). The results were not only uniform among the corporate report preparers, the auditors and the users in this study, but they were consistent with those in the MIA-ACCA (2016) survey (49.2\% answered 'Yes,' $40.9 \%$ answered 'Maybe' and 9.9\% answered 'No').

The majority of the respondents (35\%) also believed that IR will have to be subject to independent assurance, much like financial statements. In addition, 33\% of the respondents suggested a combined assurance approach in which management, internal auditors, and external auditors share the responsibility of ensuring the reliability of the integrated reports. Another 32\% believed that, in today's technology-enabled transparent world, companies can only earn credibility and trust through their actions and constant communication.

Based on the results of this study, none of the options gained a significant majority among the respondents. However, the largest proportion of the respondents expected that the integrated reports will receive similar treatment to the financial statements published by 
companies. This perception is also shared among knowledgeable respondents, with $44 \%$ stating that independent assurance is needed. Simnett and Huggins (2015) and Atkins and Maroun (2015) also discuss the importance of obtaining assurance for integrated reports. Independent external assurance is seen as an important mechanism to enhance the reliability and credibility of integrated reports.

\subsection{Implementation and Impact}

Similar to the Malaysian survey, the majority of the respondents $(85 \%)$ believed that, if IR is to be implemented in Indonesia, then it should be driven by regulation (being either fully mandatory or on an 'apply or explain' basis). Given three options and 'other', where respondents could provide their own suggestion, $48 \%$ of the respondents expressed the belief that IR should be 'regulatory driven - mandatory', 37\% 'regulatory driven - apply or explain', and 15\% market-driven, i.e. not mandated (Figure 3). Incidentally, in the questionnaire, 'market-driven' was the first option provided, and yet it was the least popular response. Similar results were obtained from knowledgeable respondents (52\%, 32\%, and 16\%, respectively). However, these results differ from those in the MIA-ACCA (2016) survey, where the 'applyor-explain' approach was the preferred method, followed by the market-driven and mandatory bases. In addition, two respondents commented that moves towards mandating IR should progress gradually, given the substantial cost of implementation. Stubbs and Higgins (2018) also found support for mandating IR in order to increase reporting quality.

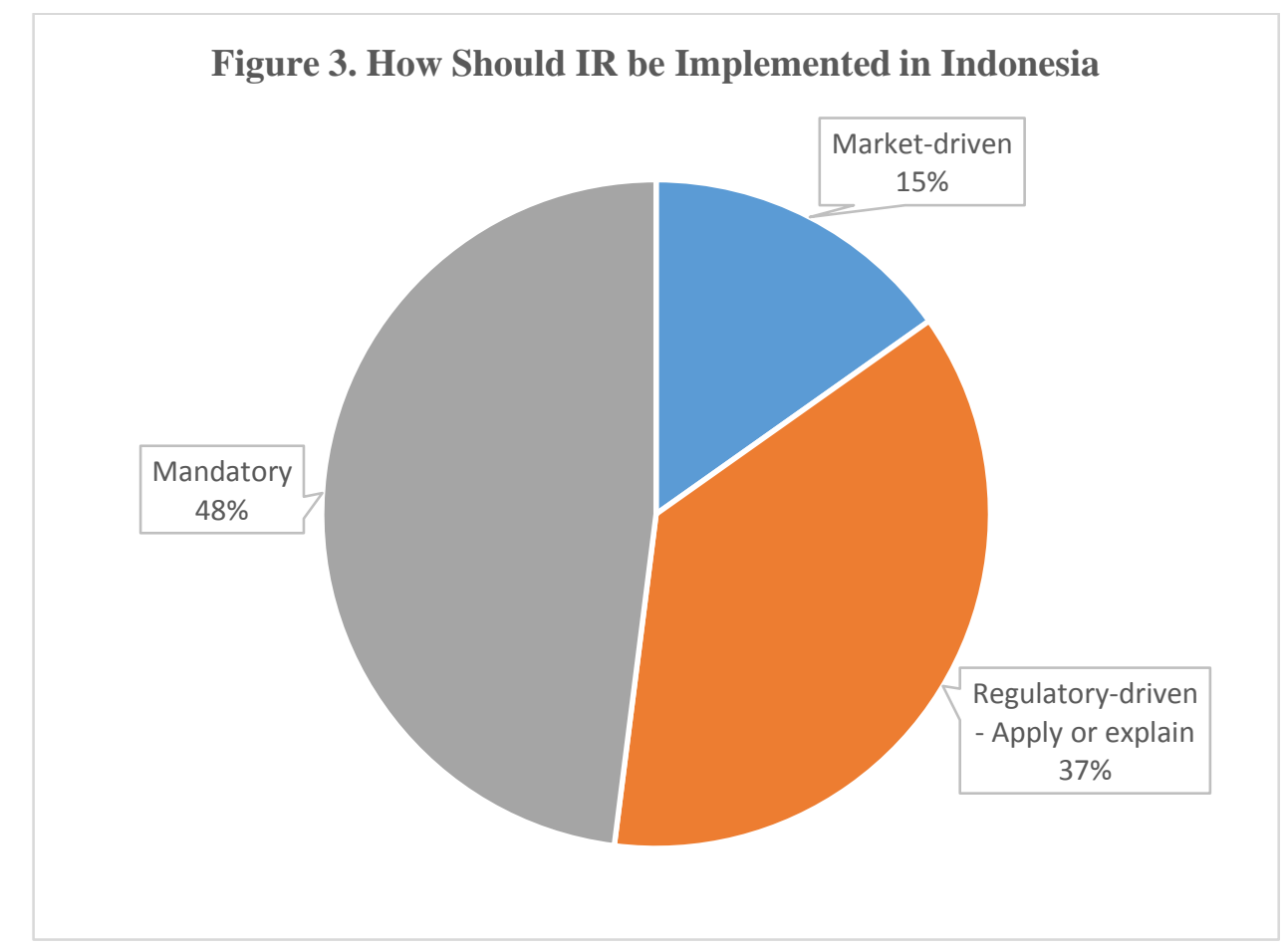

More than two-thirds (66\%) of the respondents believed that the widespread use of IR in Indonesia would make it a more attractive location for conducting business, while $31 \%$ 
were unsure and $3 \%$ disagreed with this idea. The positive findings in the present study were higher than those in the MIA-ACCA (2016) survey (54\%), reflecting the higher optimism about the benefits that IR may bring to the business climate. Among the corporate report preparers, CFOs and other finance function personnel (76\%) were most likely to see the benefits of IR in Indonesia. Among the other stakeholders, academics (46\%) and auditors (33\%) were more likely to see such benefits in Indonesia, presumably because these groups have been more exposed to IR and its advantages.

Finally, in terms of the level of knowledge, $61 \%$ of the respondents (preparers and users) with at least some knowledge of IR were more likely to see the benefits of IR in Indonesia, compared to $39 \%$ of those with little or no knowledge. Again, this indicates the importance of creating awareness about IR and how this approach can enhance the country's attractiveness to investors.

\subsection{Support, Promotion, and Training}

The findings of this study indicate that there has been strong interest in IR in Indonesia, but the respondents highlighted the need for more support by the government, its agencies and industry associations in order to effectively implement this approach. According to the respondents, such support includes a reasonable timeframe for implementation (28\%) and financial incentives for adopting IR (28\%). In regard to the latter, the Indonesian Authority of Financial Services mentioned incentives in Article 9 of its latest regulation (POJK No. 3/51/2017). Such incentives include, but are not limited to: (1) the inclusion of financial services institutions, issuers and public companies in human resources competency development programmes; (2) conferment of sustainable finance awards; and/or (3) other incentives. One respondent commented that the incentive of tax reductions might attract companies to adopt IR at a faster rate. Approximately $19 \%$ of the respondents would like some form of recognition for adopting IR. According to the respondents, the next support required is technical and preparation advice (25\%), which is consistent with the lack of guidance on how to prepare an integrated report, one of the top challenges in IR implementation (Figure 2). The results are not much different from knowledgeable respondents' perceptions $(30 \%$ for the reasonable timeframe, $25 \%$ for financial incentives, $23 \%$ for recognition, and $21 \%$ for technical and preparation advice).

The respondents also pointed out several activities that could be conducted by the IAI or other professional accounting bodies in order to enhance the knowledge of IR and promote this approach in Indonesia (Table 12). 
Table 12. Possible Activities Conducted by Professional Accounting Bodies

\begin{tabular}{|l|c|}
\hline & \multicolumn{1}{|c|}{$\begin{array}{c}\text { Percentage of } \\
\text { the respondents }\end{array}$} \\
\hline $\begin{array}{l}\text { Conduct training seminars and workshops on preparing integrated } \\
\text { reports. }\end{array}$ & $58 \%$ \\
\hline Conduct research on the benefits and costs of IR. & $34 \%$ \\
\hline $\begin{array}{l}\text { Create a platform for IR adopters to share practices and address } \\
\text { implementation challenges. }\end{array}$ & $28 \%$ \\
\hline Showcase the best practices of IR from overseas. & $23 \%$ \\
\hline $\begin{array}{l}\text { Create effective communication channels to supply timely and } \\
\text { relevant updates from the International Integrated Reporting } \\
\text { Council and its equivalents. }\end{array}$ & $19 \%$ \\
\hline Provide technical advice and consultancy on IR. & $17 \%$ \\
\hline $\begin{array}{l}\text { Provide due recognition to IR adopters, e.g., national level and/or } \\
\text { international level awards. }\end{array}$ & \\
\hline
\end{tabular}

In sum, the majority of companies in Indonesia have yet to explore the potential benefits and processes of IR. Therefore, training, conferences, and seminars should focus on the concept of IR, including its technical aspects, its benefits and its practices around the world.

\section{Conclusion}

The present study examined the perspectives of corporate report preparers and other stakeholders to understand whether Indonesia, the largest ASEAN country, is ready to move towards IR. The main research questions are: "What is the current level of IR knowledge in Indonesia?", "What are the perceived challenges and benefits for report preparers and stakeholders?", and "If IR is to be adopted in Indonesia, what form should adoption take and what is needed to support widespread adoption?"

The findings indicate low levels of knowledge about IR in Indonesia, indicating that there may be a need for training through teaching, seminars, and workshops. IR may also have to be introduced into the accounting curriculum at universities. Interestingly, the accounting academics in this study, who may be expected to be more knowledgeable regarding new developments, had no better understanding of IR than other stakeholder groups.

More knowledgeable respondents believe IR will improve the quality of corporate reporting. However, they are also concerned regarding the cost of IR implementation and the lack of supporting information systems. Furthermore, reporters' responses appeared to be contradictory, since they claimed to harbour positive views regarding the benefits of IR, but were reluctant to move towards implementation. Thus, future research could further explore the reasons for this reluctance. The findings around reluctance to implement reflect some of the challenges of IR implementation, and show some similarities to the barriers identified by Dumay et al. (2017). Another barrier, i.e., the lack of connectivity and an integration process within the organisation, was said to be implications for IR internal processes. Furthermore, Dumay and Dai (2017) stated that combining financial and non-financial information to 
produce an integrated report requires structural and cultural changes to the decision-making process. This implies that the possible barriers to implementing IR should be identified and further examined. There may also be a need to examine the impact of IR on top management thinking and the internal transformations that occur when firms embark on the IR journey.

Another finding is that for wider adoption, respondents suggest the need for mandatory adoption through regulations by local regulators or standard setters, which reminds of coercive pressures in institutional theory. Indonesians appear to expect regulation in this area, e.g., CSR activities have been mandated since 2007 (Law number 40) in Indonesia. This Law also stipulates that companies should disclose the implementation of social and environmental responsibilities in the annual report. Gunarathne and Senaratne (2018) show that Sri Lanka has a high rate of IR adoption, because of factors such as ample availability of professional accountants, a high level of stakeholder demand, a supportive accounting profession, intense competition among organizations, and cultural support. Future studies can take a similar approach to investigate the possibility of IR implementation in Indonesia. Qualitative factors, such as the role of leadership/leadership style (Adams, 2015) in IR adoption, can also be explored in future studies.

The findings from this study regarding the low level of IR knowledge in Indonesia have several practical implications. There may be a need for IR training, through teaching, seminars, conferences, and the inclusion of IR in university curricula to educate current and future report preparers and stakeholders. Regulators may also consider gradually transitioning toward IR by way of regulation or incentives for adoption. Alternatively, IR may never find favour in Indonesia. The findings from this study have implications for the IIRC in their efforts to promote IR. IR acceptance as the new reporting framework requires preparers and other stakeholders to view IR positively, including believing that IR holds advantages compared to traditional reporting. Future studies could explore the perceived strengths and weaknesses of IR in greater depth, as well as the benefits and challenges of Indonesian IR adopters, as and when such case cites become available.

IR adoption may also impact Indonesian social and environmental matters. Highquality reporting has the potential to attract foreign investor and support capital flows into the region, and thus indirectly influence economic and social well-being. In addition, considering Indonesian environmental problems, IR implementation may also contribute to increased consideration of societal well-being and the environment (Adams, 2015).

This study contributes to the literature on the potential for IR adoption in an important emerging market. However, the 'jury is still out' on whether the International IR Framework will follow the same pattern of rapid adoption as the International Financial Reporting Standards in Asia. 


\section{Appendix: Questions}

1. Respondents' data

a. Are you a member of any professional accountancy body?

b. Which reporting stakeholder category best fits you?

c. In which industry do you work?

d. What is your company's market capitalisation?

e. Is your company a State-Owned Enterprise (SOE)?

2. Awareness of IR

a. How much do you know about Integrated Reporting $(<\mathrm{IR}\rangle)$ ? (Please answer on a scale of 1 to 5 where $1=$ No knowledge; $5=$ In-depth knowledge)

b. Do you plan to know more about $<\mathrm{IR}>$ ?

c. Has $<\mathrm{IR}>$ been discussed at the Board level of your company?

d. Would your company consider adopting $<\mathrm{IR}>$ ?

e. Would you consider yourself an active advocate of $<\mathrm{IR}>$ ?

f. What is the key difference between <IR > and CSR/Sustainability Reports?

3. Perceived benefits of IR

a. Does the current corporate reporting framework allow you to adequately communicate the value and value-creating potential of your company to investors and other stakeholders?

b. Do you believe that $\langle\mathrm{IR}\rangle$ will help to improve the current corporate reporting of your company?

c. Are you able to get sufficient information about the value and value-creating potential of a company by looking at their current suite of corporate reporting?

d. Do you believe that $\langle\mathrm{IR}\rangle$ will help to improve corporate reporting?

e. What are the perceived benefit(s) in adopting $\langle\mathrm{IR}>$ ?

f. Assuming that the current benefits derived from corporate reporting is given a score of 50, how would you score the benefits of $\langle\mathrm{IR}>$ using current corporate reporting as a baseline?

g. What do you believe would provide the greatest motivation for your company to prepare an Integrated Reporting? (You can choose more than 1)

4. Perceived challenges of IR

a. What do you foresee are the top three challenge(s) in adopting $<$ IR $>$ ?

b. If your company prepares a separate Sustainability Report, will this continue to be prepared in addition to the Integrated Reporting? Why or why not?

c. Assuming that the current cost of preparing your corporate reports is given a score of 50 , how would you score the cost of preparing <IR> for your company using the current cost of preparing corporate reports for your company as a baseline?

d. Assuming that the current effort expended by your company in preparing the corporate reports is given a score of 50, how would you score the expected effort of preparing $<\mathrm{IR}>$ for your company using the current effort of preparing corporate reports for your company as a baseline?

5. Primary recipients and preparers of IR

a. Who should be the primary recipient(s) of the $\langle\mathrm{IR}>$ ?

b. Who should be primarily responsible for preparing the $\langle$ IR $>$ ?

c. How important is the role of leadership/leadership style in determining the introduction of IR?

d. Do you think stakeholders will require the $<\mathrm{IR}>$ to be audited in order for them to rely on the reports?

e. If stakeholders require assurance for $\langle\mathrm{IR}\rangle$, what do you think is the most appropriate form and level of assurance to be given in the following areas of information?

f. Which of the following statements best reflects your views about increasing reliability of an $\langle\mathrm{IR}>$ ? 
6. Standards and Implementation

a. If $\langle\mathrm{IR}>$ is to be implemented, how should it be implemented in Indonesia?

b. If $\langle\mathrm{IR}>$ is commonly used by companies in Indonesia, do you believe that its use will make Indonesia a more attractive place for doing business?

c. If $\langle$ IR $\rangle$ is commonly used by companies in Indonesia, do you believe that its use will make Indonesian businesses more attractive to investors?

7. Support, Promotion, and Training

a. If $\langle\mathrm{IR}>$ is to be commonly used in Indonesia, what will be your preference with respect to the following kinds of support that you may expect from the government, its agencies and industry associations, etc.?

b. What can IAI and other professional accounting bodies do to enhance the knowledge of and to promote <IR> in Indonesia? 


\section{References}

Abeysekera, I. (2013). A template for integrated reporting. Journal of Intellectual Capital, 14(2), 227-245.

Abhayawansa, S., Elijido- Ten, E., \& Dumay, J. (2018). A practice theoretical analysis of the irrelevance of integrated reporting to mainstream sell- side analysts. Accounting \& Finance.

Adams, C. A. (2015). The international integrated reporting council: a call to action. Critical Perspectives on Accounting, 27, 23-28.

Ahmed Haji, A. \& Anifowose, M. (2016). Audit committee and integrated reporting practice: does internal assurance matter? Managerial Auditing Journal, 31(8/9), 915-948.

Atkins, J., \& Maroun, W. (2015). Integrated reporting in South Africa in 2012: Perspectives from South African institutional investors. Meditari Accountancy Research, 23(2), 197-221.

Basalamah, A. S., \& Jermias, J. (2005). Social and environmental reporting and auditing in Indonesia: maintaining organizational legitimacy? Gadjah Mada International Journal of Business, 7(1), 109-127.

Beck, C., Dumay, J., \& Frost, G. (2017). In pursuit of a 'single source of truth': from threatened legitimacy to integrated reporting. Journal of Business Ethics, 141(1), 191-205.

Berndt, T., Bilolo, C., \& Müller, L. (2014, April). The future of integrated reporting. In 4th annual international conference on accounting and finance. Thailand, Phuket (pp. 28-29).

Centre for Governance, Institutions, \& Organisations. (2016). Sustainability Reporting in ASEAN: State of Progress in Indonesia, Malaysia, Singapore and Thailand. Singapore: NUS Business School.

Chaidali, P. P., \& Jones, M. J. (2017). It's a matter of trust: Exploring the perceptions of Integrated Reporting preparers. Critical Perspectives on Accounting, 48, 1-20.

Cho, C. H., Phillips, J. R., Hageman, A. M., \& Patten, D. M. (2009). Media richness, user trust, and perceptions of corporate social responsibility: An experimental investigation of visual web site disclosures. Accounting, Auditing \& Accountability Journal, 22(6), 933-952.

CIA. (2017). The world fact-book 2017: Indonesia, Available online at: http://www.cia.gov/cia/publications/factbook/geos/id.html. Accessed on: 21 January 2018.

Claessens, S., Djankov, S., Fan, J. P., \& Lang, L. H. (1999). Expropriation of minority shareholders: Evidence from East Asia(pp. 461-498). Washington, DC: World Bank.

Claessens, S., Djankov, S., \& Lang, L. H. (2000). The separation of ownership and control in East Asian corporations. Journal of Financial Economics, 58(1), 81-112.

Colvert, K. (2016, May 13). Integrated reporting: the view from Asia. HKICS. Retrieved from http://csj.hkics.org.hk/site/2016/05/13/integrated-reporting-the-view-from-asia/.

Deegan, C., \& Rankin, M. (1997). The materiality of environmental information to users of annual reports. Accounting, Auditing \& Accountability Journal, 10(4), 562-583.

Deegan, C. (2002). Introduction: The legitimising effect of social and environmental disclosures-a theoretical foundation. Accounting, Auditing \& Accountability Journal, 15(3), 282-311.

de Villiers, C. (1999). The Decision by Management to Disclose Environmental Information: A research note based on interviews. Meditari Accountancy Research, 7, 33-48.

de Villiers, C., Rinaldi, L., \& Unerman, J. (2014). Integrated Reporting: Insights, gaps and an agenda for future research. Accounting, Auditing \& Accountability Journal, 27(7), 1042-1067.

de Villiers, C., \& van Staden, C. J. (2006). Can less environmental disclosure have a legitimising effect? Evidence from Africa. Accounting, Organizations and Society, 31(8), 763-781.

de Villiers, C., \& Van Staden, C. J. (2010). Shareholders' requirements for corporate environmental disclosures: A cross country comparison. The British Accounting Review, 42(4), 227-240.

de Villiers, C., \& van Staden, C. (2012). New Zealand shareholder attitudes towards corporate environmental disclosure. Pacific Accounting Review, 24(2), 186-210.

de Villiers, C., \& Hsiao, P.-C. K. (2018). Integrated Reporting, in de Villiers, C, \& Maroun, W. (Eds.) Sustainability accounting and integrated reporting, Routledge: Abingdon, UK.

de Villiers, C., Hsiao, P.-C.K. \& Maroun, W. (2017a). Developing a conceptual model of influences around integrated reporting, new insights, and directions for future research. Meditari Accountancy Research, 25(4), 450-460. 
de Villiers, C., Venter, E.R., \& Hsiao, P.C.K. (2017b), "Integrated reporting: background, measurement issues, approaches and an agenda for future research," Accounting \& Finance, 57(4), 937-959.

de Villiers, CJ. \& Vorster, Q. (1995), “More Corporate Environmental Reporting in South Africa?”, Meditari Accountancy Research, 3, 44-66.

Dvořák, T. (2005). Do domestic investors have an information advantage? Evidence from Indonesia. The Journal of Finance, 60(2), 817-839.

du Toit, E., van Zyl, R., \& Schütte, G. (2017). Integrated reporting by South African companies: a case study. Meditari Accountancy Research, 25(4), 654-674.

Dumay, J., Bernardi, C., Guthrie, J., \& Demartini, P. (2016). Integrated reporting: a structured literature review. Accounting Forum, 40 (3), 166-185.

Dumay, J., Bernardi, C., Guthrie, J., \& La Torre, M. (2017). Barriers to implementing the International Integrated Reporting Framework: A contemporary academic perspective. Meditari Accountancy Research, 25(4), 461-480.

Dumay, J., \& Dai, T. (2017). Integrated thinking as a cultural control? Meditari Accountancy Research, 25(4), 574-604.

Eccles, R., \& Armbrester, K. (2011), "Integrated reporting in the cloud”, IESE Insight, Vol. 8 No. 1, pp. 13-20.

Esterhuyse, L., \& Wingard, C. (2016). An exploration of the online investor relations (IR) practices of companies listed on the Johannesburg Stock Exchange (JSE). South African Journal of Economic and Management Sciences, 19(2), 215-231.

EY (2014). EY's excellence in integrated reporting awards, available at: www.ey.com/Publication/ vwLUAssets/EY-Excellence-In-Integrated-Reporting-2014/\$FILE/EY-Excellence-InIntegratedReporting-2014.pdf (accessed 13 January 2018).

García-Sánchez, I. M., Rodríguez-Ariza, L., \& Frías-Aceituno, J. V. (2013). The cultural system and integrated reporting. International Business Review, 22(5), 828-838.

Gray, R., Kouhy, R., \& Lavers, S. (1995). Corporate social and environmental reporting: a review of the literature and a longitudinal study of UK disclosure. Accounting, Auditing \& Accountability Journal, 8(2), 47-77.

Gunarathne, A. N., \& Senaratne, S. (2018). Country Readiness in Adopting Integrated Reporting: A Diamond Theory Approach from an Asian Pacific Economy. In Accounting for Sustainability: Asia Pacific Perspectives (pp. 39-66). Springer, Cham.

Gunawan, J. (2007). Corporate social disclosures by Indonesian listed companies: a pilot study. Social Responsibility Journal, 3(3), 26-34.

Gunawan, J. (2015). Corporate social disclosures in Indonesia: stakeholders' influence and motivation. Social Responsibility Journal, 11(3), 535-552.

Guthrie, J., Manes-Rossi, F., \& Orelli, R. L. (2017). Integrated Reporting and Integrated Thinking in Italian Public Sector Organisations. Meditari Accountancy Research, 25(4), forthcoming.

Higgins, C., \& Larrinaga, C. (2014), "Sustainability reporting: Insights from institutional theory", in Unerman, J. Bebbington, J. and O'Dwyer B. (Eds), 2nd ed., Sustainability Accounting and Accountability, Routledge, London, pp. 273-285.

Higgins, C., Stubbs, W., \& Love, T. (2014). Walking the talk (s): Organisational narratives of integrated reporting. Accounting, Auditing \& Accountability Journal, 27(7), 1090-1119.

Hsiao, P. C. K., \& Kelly, M. (2017). Investment considerations and impressions of integrated reporting: Evidence from Taiwan. Sustainability Accounting, Management and Policy Journal.

Ighian, D.S.C. (2015), Integrated reporting-the future of financial reporting, Internal Auditing and Risk Management, 38(1), 125-134.

IIRC. (2013), “The international IR framework", available at: www.theiirc.org/international-irframework/ (accessed 13 January 2018).

ISCA-NUS. (2014). Integrated Reporting Survey 2014. Retrieved from http://download.icpas.org.sg/ind/ISCA\%20NUS\%20Integrated\%20Reporting\%20Survey\%20 2014.pdf.

James, M. L. (2015). The Benefits of Sustainability and Integrated Reporting: An Investigation of Accounting Majors' Perceptions. Journal of Legal, Ethical and Regulatory Issues, 18(1), 1. 
Joseph, C., Gunawan, J., Sawani, Y., Rahmat, M., Noyem, J. A., \& Darus, F. (2016). A comparative study of anti-corruption practice disclosure among Malaysian and Indonesian Corporate Social Responsibility (CSR) best practice companies. Journal of cleaner production, 112, 2896-2906.

Kartini, D. (2017, October 19). Investor local menjadi tuan di bursa sendiri. Kontan. Retrieved from https://investasi.kontan.co.id/news/investor-lokal-menjadi-tuan-di-bursa-sendiri.

Lai, A., Melloni, G., \& Stacchezzini, R. (2017). What does materiality mean to integrated reporting preparers? An empirical exploration. Meditari Accountancy Research, 25(4), 533-552.

Lodhia, S. (2015). Exploring the transition to integrated reporting through a practice lens: an Australian customer owned bank perspective. Journal of Business Ethics, 129(3), 585-598.

Macias, H. A., \& Farfan-Lievano, A. (2017). Integrated reporting as a strategy for firm growth: multiple case study in Colombia. Meditari Accountancy Research, 25(4), 605-628.

Mahzan, N. (2017, November 28). MIA's journey to the adoption of integrated reporting. Malaysian Reserve. Retrieved from https://themalaysianreserve.com/2017/11/28/mias-journey-adoptionintegrated-reporting/.

McNally, M. A., Cerbone, D., \& Maroun, W. (2017). Exploring the challenges of preparing an integrated report. Meditari Accountancy Research, 25(4), 481-504.

MIA-ACCA. (2016). Integrated Reporting Survey. Retrieved from http://www.accaglobal.com/content/dam/ACCA_National/my/dis/MIA-ACCA-IR-surveyreport_2016.pdf.

Michelon, G., Pilonato, S., \& Ricceri, F. (2015). CSR reporting practices and the quality of disclosure: An empirical analysis. Critical perspectives on accounting, 33, 59-78.

Nasution, R. M., \& Adhariani, D. (2016). Simbolis Atau Substantif? Analisis Praktik Pelaporan CSR Dan Kualitas Pengungkapan. Jurnal Akuntansi dan Keuangan Indonesia, 13(1), 23-51.

Owen, G. (2013). Integrated reporting: A review of developments and their implications for the accounting curriculum. Accounting Education, 22(4), 340-356.

Perego, P., Kennedy, S., \& Whiteman, G. (2016). A lot of icing but little cake? Taking integrated reporting forward. Journal of cleaner production, 136, 53-64.

Raaijmakers, A. G., Vermeulen, P. A., Meeus, M. T., \& Zietsma, C. (2015). I need time! Exploring pathways to compliance under institutional complexity. Academy of Management Journal, 58(1), 85-110.

Rensburg, R., \& Botha, E. (2014). Is Integrated Reporting the silver bullet of financial communication? A stakeholder perspective from South Africa. Public Relations Review, 40(2), 144-152.

Roberts, R. W. (1992). Determinants of corporate social responsibility disclosure: An application of stakeholder theory. Accounting, Organizations and Society, 17(6), 595-612.

Serafeim, G. (2015). Integrated reporting and investor clientele. Journal of Applied Corporate Finance, 27(2), 34-51.

Simnett, R., \& Huggins, A. L. (2015). Integrated reporting and assurance: where can research add value?. Sustainability Accounting, Management and Policy Journal, 6(1), 29-53.

Siregar, S.V, \& Bachtiar, Y. (2010). Corporate social reporting: empirical evidence from Indonesia Stock Exchange. International Journal of Islamic and Middle Eastern Finance and Management, 3(3), 241-252.

Slack, R., \& Tsalavoutas, I. (2018). Integrated reporting decision usefulness: mainstream equity market views. Accounting Forum, 42(2), 184-198.

Solomon, A., \& Lewis, L. (2002), "Incentives and disincentives for corporate environmental disclosure", Business Strategy \& the Environment, Vol. 11 No. 2, pp. 154-169.

Soyka, P. A. 2013. The international integrated reporting council (IIRC) integrated reporting framework: Toward better sustainability reporting and (Way) beyond. Environmental Quality Management, 23, 1-14.

Steyn, M. (2014). Organisational benefits and implementation challenges of mandatory integrated reporting: Perspectives of senior executives at South African listed companies. Sustainability Accounting, Management and Policy Journal, 5(4), 476-503.

Stubbs, W., \& Higgins, C. (2018). Stakeholders' perspectives on the role of regulatory reform in integrated reporting. Journal of Business Ethics, 147(3), 489-508. 
Tsamenyi, M., Noormansyah, I., \& Uddin, S. (2008). Management controls in family-owned businesses (FOBs): A case study of an Indonesian family-owned University. Accounting Forum, 32(1), 62-74.

Utama, C. A. (2012). Company disclosure in Indonesia: Corporate governance practice, ownership structure, competition and total assets. Asian journal of business and accounting, 5(1), 75-108.

Utama, C. A., \& Utama, S. (2014). Determinants of disclosure level of related party transactions in Indonesia. International Journal of Disclosure and Governance, 11(1), 74-98. 